\title{
Arquivos de Neuro-Psiquiatria has new Editors
}

\author{
Arquivos de Neuro-Psiquiatria tem novos Editores \\ Luís dos Ramos Machado and José Antonio Livramento
}

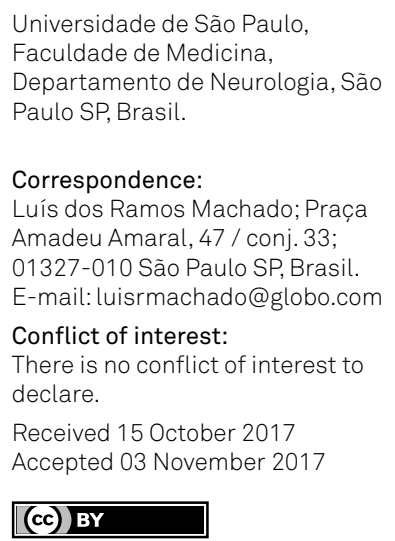

Universidade de São Paulo, Faculdade de Medicina, Departamento de Neurologia, São Paulo SP, Brasil.

Correspondence:

Luís dos Ramos Machado; Praça

Amadeu Amaral, 47 / conj. 33;

01327-010 São Paulo SP, Brasil.

E-mail: Luisrmachado@globo.com

Conflict of interest:

There is no conflict of interest to declare.

Received 15 October 2017

Accepted 03 November 2017

(cc) BY

W

hen Prof. Spina França passed away in 2010, José Antonio Livramento and Luís dos Ramos Machado took over the position of editors of Arquivos de Neuro-Psiquiatria (ANP). Upon taking the reins, they proposed that the modus operandi of the journal should be renewed, through implementation of a series of guiding principles grounded in the work of the editors who had preceded them.

The first of these principles was that the almost family-like editorial organization should gradually be wound up. Then, this was the only strategy possible, and it was vital not only at the beginning but also during the difficult years of consolidation of the journal. The personal dedication, sacrifice and efforts made by Oswaldo Lange, Antonio Spina França Netto, Marília Lange Spina França and Adriana Spina França Machado during long days of work need to be highlighted. Likewise, the enormous help given by Silvia Regina Mielli and the collaboration of the present editors need to be noted. This harmonious teamwork was always done on a strictly voluntary basis without remuneration. This ensured absolute regularity of publication of the journal over a period of decades, along with the high quality of papers published, which has made ANP the most significant journal of neurology in Latin America. That phase was notable for the editorial talent of Spina França, who modernized the journal and gave it its current features.

The second of these principles consisted of increasing the number of associate editors. We now have 84 associate editors who act in 19 areas of the neurosciences. There were two main reasons for this: to avoid overloading each of the associate editors and to bring specialists of all ages from all regions of Brazil into editorial activity. From their work as associate editors, some of them might emerge as having a vocation for continuing our work as editors. And this has happened.

The third of these principles consisted of seeking to improve the impact factor of ANP. To this end, we have changed the periodicity of the journal, so that it is now published every month; we have become more rigorous in making selections from the articles submitted; and we have taken a more interventionist stance in relation to articles with conceptual or form problems but with good potential quality. In parallel, with the aid of Carlos Alberto Mantovani Guerreiro, we have been able to count on absolutely professional revision of English for all articles for just over a year now. This has substantially modified the presentation of our manuscripts, which have come to use language that is totally consonant with that used in major international journals within the neurosciences. Despite all the difficulties, over the five years covered by this assessment of our editorial activity, we have succeeded in tripling the impact factor of ANP.

The fourth of these principles consisted of consolidating the journal in reality and in law as the official journal of the Brazilian Academy of Neurology (ABN). The Associação Arquivos de Neuro-Psiquiatria Dr. Oswaldo Lange (AANPOL), which was the owner of ANP, transferred ownership of the journal to the ABN without charge, without debts and without any financial liabilities. This cost-free transfer included the office suite that forms the head office of ANP and the savings that had resulted from years of work and a very efficient administration. In this undertaking, the absolutely elegant and academic stance taken by all members of AANPOL and also the fundamental participation of the directorate of the ABN at that time, especially its president, Rubens José Gagliardi, needs to be highlighted.

The fifth of these principles consisted of preparing the successions to the positions of editor of ANP. Almost three years ago, specifically at our request, the ABN nominated 
an ad hoc committee to choose the next editors of ANP. This committee was formed by five members, and we participated in it as the current editors. Carlos Alberto Mantovani Guerreiro and Hélio Afonso Ghizoni Teive were unanimously nominated, and they kindly accepted the invitation from the ABN. It was agreed that, over this period, we would have the task of providing training specifically directed towards performing these activities. However, in October 2016, Carlos Guerreiro contacted us to decline the invitation to be one of the editors, strictly for personal reasons. To replace him, we sent an invitation to Paulo Caramelli who was, at that time, at the end of his term of office as president of the Brazilian Congress of
Neurology. He kindly accepted the invitation, despite the short period available for training.

Thus, we are now handing over the reins of ANP to our friends Hélio Teive and Paulo Caramelli. With slightly more than six years of editorial activity, we feel that we have expanded the reach of the journal and have helped it to surmount major historical difficulties with dignity. Among these, we can highlight the satisfactory resolution of the awkward position of ANP within the national scientific arena when it did not have any solid links with the ABN.

We wish them a modern and intelligent editorship, as it certainly will be.

Hélio and Paulo, welcome! 